\title{
Exposure to Airborne Bacteria During Sport Activities Indoors: Preliminary Studies in the Small Halls Without Heating, Ventilation and Air Conditioning (HVAC) System
}

\author{
Pastuszka JS ${ }^{1 *}$ and Brągoszewska $\mathrm{E}^{2}$ \\ ${ }^{1}$ Department of Air Protection, Silesian University of Technology, Poland \\ ${ }^{2}$ Department of Technologies and Installations for Waste Management, Silesian University of Technology, Poland
}

*Corresponding author: Jozef S Pastuszka, Department of Air Protection, Silesian University of Technology, 22B Konarskiego St., 44-100 Gliwice, Poland.

To Cite This Article: Pastuszka JS, Bragoszewska E. Exposure to Airborne Bacteria During Sport Activities Indoors: Preliminary Studies in the Small Halls Without Heating, Ventilation and Air Conditioning (HVAC) System. Am J Biomed Sci \& Res. 2021 - 13(5). AJBSR.MS.ID.001917. DOI: 10.34297/AJBSR.2021.13.001917.

Received: 眥 July 26, 2021; Published: 制 August 03, 2021

\begin{abstract}
This work presents the concentration levels of the bacterial aerosol in two small sports halls in the Upper Silesia, Poland. The samples of airborne bacteria were collected using 6-stage Andersen cascade impactor (with aerodynamic cut-size diameters of 7.0, 4.7, 3.3, 2.1, 1.1 and 0.65 $\mu \mathrm{m})$. Obtained results show that during sports activity there is a clear increase in the concentration of bacterial aerosol. The concentration of bacterial aerosol in the school gym was very high already in the first hour of classes, and it was growing rapidly from one lesson to another, reaching the level above $104 \mathrm{CFU} \mathrm{m}^{-3}$. Sport activity in the gym significantly changed the patterns of the size distribution of airborne bacteria, shifting the peak from the size range of 3.3-4.7 $\mu \mathrm{m}$, to smaller bacterial particles - in the range from 1.1 to $2.1 \mu \mathrm{m}$. Using the obtained data, the dose of viable bacteria, inhaled during exposure, to the body weight of the exposed student in the gym (BID) was calculated. BID ranged from 296 to $660 \mathrm{CFU} \mathrm{kg}^{-1}$. The analysis of the bacteria species showed that bacteria of human origin, dominated in the tested air, mainly emitted from the respiratory tract and human skin. Especially, Gram-positive cocci and nonsporting Gram-positive rods were the dominant species there. It seems that exposure to the bacterial aerosol in the sports hall and gym does not pose a direct threat to health. However, long-term inhalation of such high doses of airborne bacteria can cause adverse health effects, especially in people who are allergic (allergic / atopy).
\end{abstract}

Keywords: Bioaerosol, Indoor air, Sport-induced bacteria

\section{Introduction}

As biological pollutants can cause a wide range of human disease, one of the main objectives of air monitoring should be to verify and quantify the presence of bioaerosols to assess exposure or identify their source. Bioaerosol is a two-phase system consisting of biological particles suspended in the air. These particles can be viruses, bacteria, fungi, or microscopic parts of living organisms. Bioaerosol particles can be viable or non-viable. They appear as separate biological particles or are attached to the surface of dust. The smallest bioparticles are viruses whose size ranges from 0.02 $\mu \mathrm{m}$ to $0.3 \mu \mathrm{m}$. Bacteria and microscopic fungal cells have a diameter of 0.3 to $100 \mu \mathrm{m}$, and pollen and other biological particles from 10 $\mu \mathrm{m}$ to even hundreds of micrometers [1,2].

In the case of buildings, note that microorganisms are always present in the indoor air. Human and animal organisms should be considered as the main source of bacterial aerosols (both single organisms, bacterial conglomerates and bacteria attached to solid particles) in the indoor environment. Significant amounts of bacteria are also found in the settled dust, from where they can be re-emitted into the air, for example during the movement of inhabitants. 
There is already half century of tradition and literature on research of bioaerosols in homes and offices (se, for example [17]. Airborne microbes in schools and other educational settings were also studied. Generally, reported mould and bacteria data strongly indicate that airborne microorganisms are present in many classrooms, possibly leading to health problems [8]. For example, Karwowska [9] obtained the number concentration of microorganisms ranged within $10^{2}-10^{3} \mathrm{CFU} \mathrm{m}^{-3}$ for mesophilic bacteria, 1-10 CFU m${ }^{-3}$ for haemolytic bacteria, $10-100 \mathrm{CFU} \mathrm{m}^{-3}$ for staphylococci, $0-10 \mathrm{CFU} \mathrm{m}^{-3}$ for coli group and from 10 to almost $103 \mathrm{CFU} \mathrm{m^{-3 }}$ for moulds. Similar concentration levels of airborne bacteria, between $10^{2}$ and $10^{3} \mathrm{CFU} \mathrm{m}^{-3}$, were obtained by Kim et al. [10] in indoor environment of elementary schools in Ulsan, South Korea. They found that $84 \%$ of identified bacteria were observed as Gram-positive, and Micrococcus spp. was the most abundant group with $61 \%$ of tested isolated, followed by genus Staphylococcus with $10 \%$. The study carried out by Stryjakowska-Sekulska et al. [11] in various rooms of the university buildings in Poznań, Poland, also shows that the predominant airborne bacteria were Staphylococcus spp. and Micrococcus spp. However, data on the concentration of bacterial and fungal aerosols in specific indoor environments such as indoor swimming pools, gyms, restaurants, shops, etc. are still lacking, although several studies have recently been published describing exposure to airborne microorganisms in sports facilities [12-15]. On the other hand, it should be noted that due to the specific features of this type of space, especially their cubature, microclimate, high density people and their physical activity - it is very difficult to fully estimate the concentration and structure of bioaerosols in these environments based on data obtained from other well-studied buildings. Therefore, detailed studies on the microbiological air quality in these indoor environments are still needed. In particular, the characteristics of infectious diseases occurring in sport should be investigated and combined with information on exposure to bioaerosols during sports activities. It is surprising that knowledge on this subject is still limited, and some published works suggest that exposure to airborne microorganisms may be neglected in the analysis of transmission of infections. For example, Tuberville et al. [16] identified the factors most reported in the medical literature as responsible for infectious disease outbreaks in certain sports and their modes of transmission. They identified fifty-nine reports of infectious disease outbreaks in competitive sports and found that the most common mode of transmission in the outbreaks was direct personto-person contact, while airborne and vectorial transmission was rarely reported. Therefore, it is necessary to elucidate in detail the role of exposure to airborne bacteria and viruses in various sports activities. Fortunately, the situation is starting to change, and researchers are focusing their activities on this topic [17].
The aim of the study was to find out about the properties of bacterial aerosols in the gym of the primary school and in the small municipal sports hall. Such research is important because there are still several sports facilities in Poland, as well as in other East-European countries, without adequate mechanical ventilation (HVAC).

\section{Materials and Methods}

The research was conducted in a small municipal sports hall in Bytom (bodybuilding gym) and in the gym of one of the primary schools in Katowice, in the central part of Upper Silesia, Poland, in summer season, before the coronavirus pandemic. Both studied indoor environments; sports hall and gymnastic hall did not have air conditioning. The volume of the small municipal sports hall was about $400 \mathrm{~m}^{3}$. During the measurements, there were 15 people inside the hall. The air temperature was $21.5^{\circ} \mathrm{C}$ and the relative humidity (RH) was $24 \%$. The school gymnasium had a volume of $903 \mathrm{~m}^{3}$. During our research, students aged 11 to 14 exercised in the room. The air temperature in the gym was between 21 and 23 ${ }^{\circ} \mathrm{C}$ and the relative humidity ( $\mathrm{RH}$ ) was between about $30^{-3} 5 \%$.

Air samples were collected using a 6-stage Andersen cascade impactor (with aerodynamic cut - size diameters of $7.0 ; 4.7 ; 3.3 ; 2.1$; 1.1 and $0.65 \mu \mathrm{m}$ ). Impactor was located at a height of $1.5 \mathrm{~m}$ above the floor. The pump provided a constant flow rate of $28.3 \mathrm{dm}^{3} \mathrm{~min}^{-1}$ during the measurement. The sampling time, estimated according to the optimal sampling time equation [18] in the sports hall and in the school, gym was 10 minutes and 5 minutes, respectively. Air samples were taken twice in the sports hall. The first measurement was taken before starting sports exercises and the second during classes. In the gym air samples were collected four times. The first measurement was made in the absence of classes (in empty room). The second sampling took place after a warm-up during the first physical education (PE) lesson. The classes were attended by 15 students and a sports teacher. The third air sampling was carried out during exercises in the second PE lesson with 27 students. The fourth conscription was carried out in the third lesson (29 participants). For control purposes, measurements were also taken outside the building.

Microorganisms were collected on nutrient media in Petridishes located on all impactor stages. Concentrations were calculated as colony forming units per cubic meter of air. Nutrient agar was used Tryptic Soy Agar, which was added cyclohexymide (actidione) to inhibit fungal growth. All samples were incubated for 7 days at room temperature. It should be mentioned that recently some researchers $[19,20]$ indicated that the addition of blood to a base agar provides additional growth factors such as X-factor (haemin) and V-factor (coenzyme/ NAD), which standard media 
such as TSA do not contain. Therefore, they suggested that blood agar rather than TSA could be used for bioaerosol of human origin. However, we wanted to compare the exposure to airborne bacteria in the sports halls with our previous data obtained in other indoor environments, hence we decided to apply the same methods.

Identification of bacterial isolates was based on morphological analysis: macroscopic colonies grown on agar (Trypcase Soy Agar, TSA) and microscopic cells-stained Gram [1,3\&18]. Then the strains tested were differentiated on basis of their metabolic properties, using the API biochemical tests. Also, a computer analysis system APIweb was used which allowed rapid interpretation of the API tests (bioMerieux, Marcy-l'Étoile, France).

\section{Results and Discussion}

The levels of the bacterial aerosol in the studied indoor environments presented in Figures 1 and 2 indicate an increase in the concentration of airborne bacteria during sports. Before the training, the concentration of airborne bacteria in the sports hall

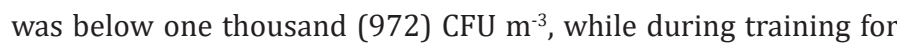
competitive sports, the concentration level more than doubled (Figure 1). The dynamics of changes in the concentration of bacterial aerosol in the gym seems to be of particularly interesting (Figure 2). During the first lesson, the level of bacteria in the air

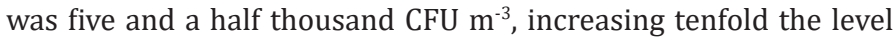
recorded before the start of the lesson.

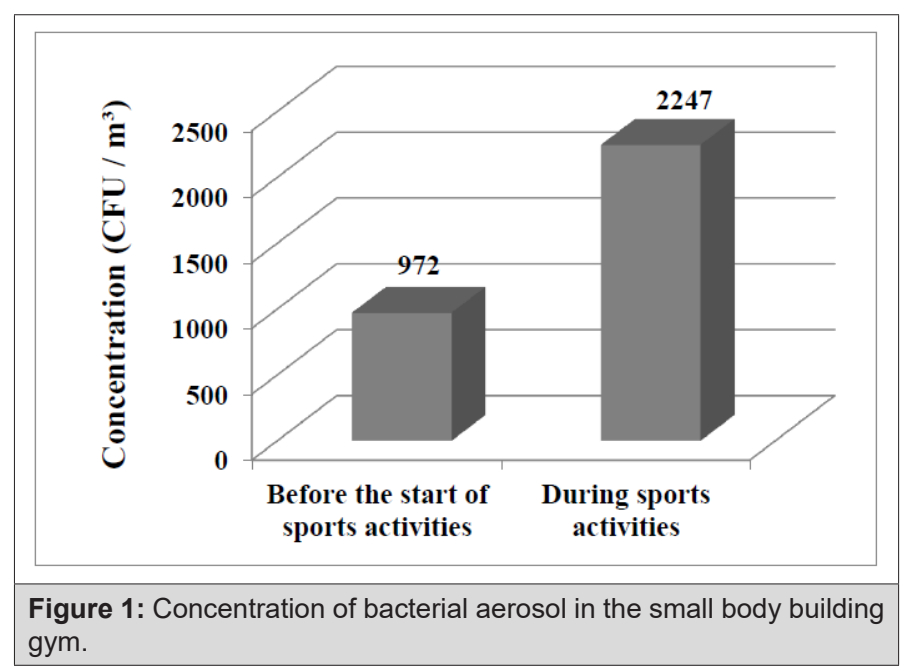

The concentration of bacteria during the third lesson reached over twelve thousand CFU $\mathrm{m}^{-3}$. Although not shown in Figure 2, we also observed that the concentration of the bacterial aerosol increased not only with the number of participants but also with the intensity of training. These results are consistent with data obtained in 41 private gymnasiums in Bari, Italy by Signorile et al. [21]. They found that during recreational physical and sport activities, the total bacterial count ranged from about 300 to over $10,000 \mathrm{CFU} \mathrm{m}{ }^{-3}$. Moreover, the concentration of airborne bacteria before class, $552 \mathrm{CFU} \mathrm{m}^{-3}$ (Figure 2), is consistent with the results obtained in classrooms in Warsaw, Poland [9] and in Lisbon, Portugal [22]. On the other hand, it should be noted that the suggested maximum level of non-pathogenic bacteria indoors is $4,500 \mathrm{CFUm}^{-3}$ [1]. According to Seltzer [23], the fact that during the third lesson (Figure 2) the concentration of airborne bacteria (certainly of human origin) exceeded 2.7 times this suggested maximum indicates crowding and poor ventilation.

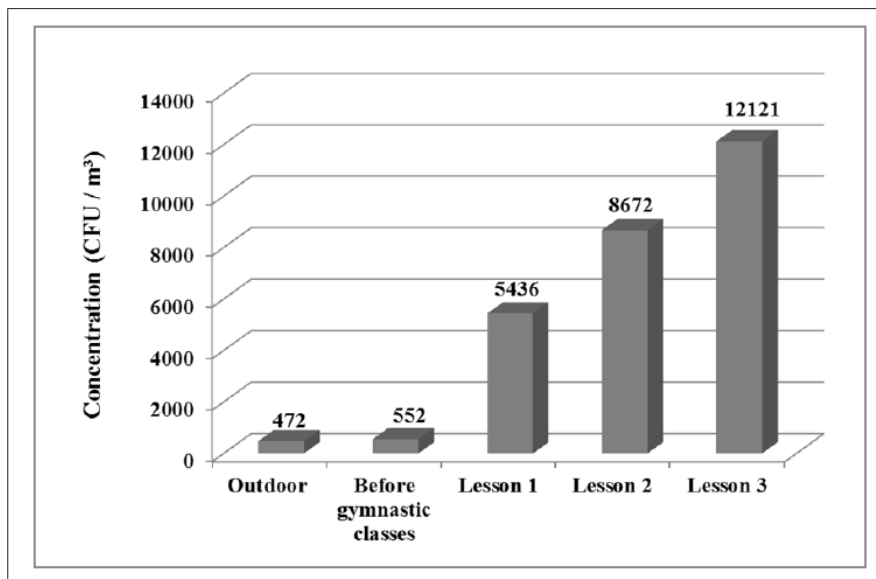

Figure 2: Concentration of bacterial aerosol in the school sports hall.

It appears useful to calculate the inhaled dose of airborne bacteria for a future in-depth analysis of the adverse health effects of inhaling live bacteria. Such an idea, following Pastuszka et al. [6] was presented by Bragoszewska et al. [30] for children attending the municipal kindergarten in Gliwice. We can calculate the total bacterial inhalation dose (TBID) or the bacterial inhalation dose (BID) depending on the weight of the exposed student. These factors can be defined as follows:

$$
\begin{aligned}
& T B I D=C \cdot I R \cdot E T(1) \\
& \text { or } B I D=\frac{C \cdot I R \cdot E T}{B W}(2)
\end{aligned}
$$

where:

TBID - the total dose of viable bacteria inhaled during the exposure, $\mathrm{CFU}$

BID - the dose of viable bacteria inhaled during exposure to the body weight of the exposed person, CFU kg-1

IR - inhalation rate coefficient, characteristic for selected activity levels, $\mathrm{m}^{3} \mathrm{~h}^{-1}$

ET - time of exposure, $\mathrm{h}$

BW - mean body weight, kg

Using the data presented in Figure 2 we can calculate the total dose of viable bacteria inhaled by students during the first, second and third lecture / sport activity (ET = 1 hour). According to the USEPA analysis [31], for students aged 11-15 years, we selected the 
IR value for the high intensity state as $2.94 \mathrm{~m}^{3} \mathrm{~h}^{-1}$. Therefore, the TBID value for each one-hour sport lecture is 15,981 CFU, 24,496 CFU and 35,636 CFU during the first, second and third sport lecture, respectively.

Estimated mean body weight (BW) of students participating in the classes was $54 \mathrm{~kg}$. Thus, the calculated BID value was 296; 454 and $660 \mathrm{CFU} \mathrm{kg}{ }^{-1}$ for the first, second and third sports lesson exposure, respectively. It should be noted that this inhaled dose is comparable to the dose inhaled by older children in a nursery (kindergarten) during a 7-hour exposure [30] and is significantly higher than the daily dose absorbed by adults in apartments in Katowice in Upper Silesia (175 CFU kg-1) [32].

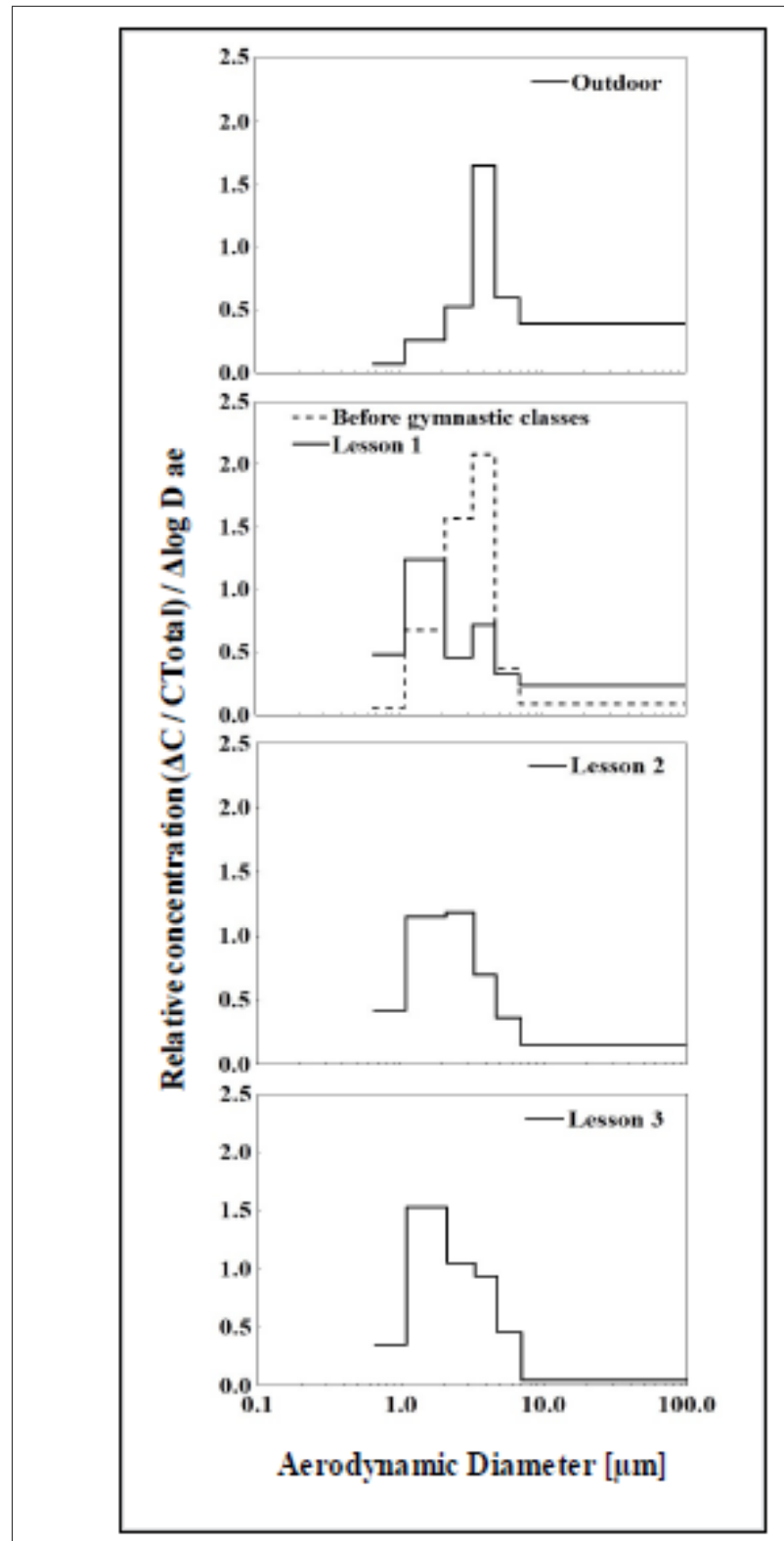

Figure 3: Size distribution of airborne bacteria in the small school sports hall.
It is also important to analyze the contribution of respirable particles to the total airborne bacteria particles. Respirable fraction contains fine particles that can penetrate the lower (deep) parts of human respiratory tract. This paper uses the old Cape Town definition limiting the inhaled fraction to particles with an aerodynamic diameter below $5 \mu \mathrm{m}$ (confirmed in 2007 by WHO [24]). It should be noted that from lesson to lesson, an increased proportion of respirable bacteria in the total bacterial aerosol was observed. In the first lesson this share was $66 \%$, and in the third it grew to $86 \%$. As the aerodynamic size of particles determines their behavior in the air and human respiratory tract, not only the concentration of bioaerosol, but also its size distribution is important for the precise prediction of its adverse health effects. The size distribution of airborne bacteria in the school sports hall is shown in Figure 3. The bacterial aerosol size distributions outside and inside - before sports activities were similar. Both distributions were unimodal with a peak in the size range of 3.3-4.7 $\mu \mathrm{m}$, however the bioaerosol indoors showed a slightly larger contribution of smaller particles and lower contribution of particles $>7 \mu \mathrm{m}$ compared to the bioaerosol outdoors. Sports activity in the gym significantly changed the patterns of this size distribution, shifting the peak to smaller bacterial particles ranging in size from 1.1 to $2.1 \mu \mathrm{m}$.

Detailed analysis of the bacterial flora of a small sports hall allowed for the identification of over 10 species of bacteria (Table 1 ). The main component of these airborne bacteria were Gram-positive cocci, mainly Staphylococcus and Micrococcus. As mentioned earlier, similar results were obtained by other researchers [10,11\&25]. Before starting sports activities in a small sports hall, these bacteria constituted $58.5 \%$ of the total concentration of bacterial aerosols (Table 1). During sports activities, the share of Gram-positive cocci in the total bacterial flora increased and amounted to $62.8 \%$. Research carried out in the school gym also showed an increase in the percentage of Gram-positive cocci from lesson to lesson. Grampositive cocci accounted for $79 \%$ of all bacterial species in the first sports lesson and increased to $88 \%$ in the second and third lessons. Since the main source of emission of this group of bacteria is the human body: the respiratory tract and the human skin, the physical activity of people in both tested halls is the most likely reason for such a significant quantitative advantage over other components of the bacterial flora in the tested air.

The remaining bacteria represent species whose natural habitat is surface water and soil. The presence of these bacteria in the tested rooms is probably related to the transfer of soil particles on shoes along with bacteria attached to them, and then their deposition on the floor. When exercising in the gym, moving people reemit dust particles containing bacteria from the floor to the air. 


\begin{tabular}{|c|c|c|}
\hline \multirow[b]{2}{*}{ Bacteria species } & \multicolumn{2}{|c|}{ (\%) of the total bacteria } \\
\hline & $\begin{array}{c}\text { before the } \\
\text { sport activities }\end{array}$ & $\begin{array}{c}\text { during the } \\
\text { sport training }\end{array}$ \\
\hline Gram-positive cocci, including: & 58.5 & 62.8 \\
\hline Kocuria rosea & - & 14 \\
\hline Micrococcus spp. & 17.2 & 11.6 \\
\hline Staphylococcus capitis & 6.9 & 2.3 \\
\hline Staphylococcus chromogenes & 10.3 & 30.2 \\
\hline Staphylococcus lentus & 17.2 & - \\
\hline Staphylococcus sciuri & 6.9 & 4.7 \\
\hline $\begin{array}{l}\text { Nonsporing Gram-positive rods, } \\
\text { including: }\end{array}$ & 24.1 & 18.6 \\
\hline Arthrobacter spp. & 13.8 & 2.3 \\
\hline Brevibacterium spp. & - & 9.3 \\
\hline Corynebacterium propinquum & - & 7 \\
\hline Corynebacterium auris & 10.3 & - \\
\hline $\begin{array}{l}\text { Gram-positive rods, family } \\
\text { Bacillacae including: }\end{array}$ & 10.4 & 9.3 \\
\hline Bacillus cereus & - & 2.3 \\
\hline Bacillus circulans & 6.9 & 2.3 \\
\hline Bacillus pumilus & 3.5 & - \\
\hline Bacillus mycoides & - & 4.7 \\
\hline Acinomycetes, including: & 7 & - \\
\hline Rhodococcus spp. & 3.5 & \\
\hline Streptomyces spp. & 3.5 & \\
\hline
\end{tabular}

It should be noted that the levels of bacterial aerosol concentrations in the investigated indoor environments are significantly higher than those recommended by the WHO for rooms designed for human habitation [1]. However, the analysis of the collected bacteria did not indicate a significant presence of pathogenic microorganisms in the air of the tested gymnasium and small sports hall. Therefore, it seems that exposure to bacterial aerosol in the tested rooms does not pose a direct risk of any acute health effects; however, prolonged inhalation of such high doses of airborne bacteria may cause some adverse health effects, especially in allergic individuals. Such individuals may be more susceptible to upper respiratory disease and allergic symptoms such as headache, watery eyes, itchy skin, coughing, and more [27]. The most vulnerable seem to be sports teachers, whose exposure time is the longest, several hours a day. However, more serious adverse health effects may arise when students become professional athletes [2729].

Our research clearly shows that it is very important to improve the microbiological quality of air in such small sports halls by providing adequate ventilation.

\section{Conclusions}

1. The concentration of bacterial aerosol in the hall before sports training was almost $1,000 \mathrm{CFU} \mathrm{m}^{-3}$ and more than doubled during sports activities.

2. The concentration of bacterial aerosols in the gym was very high already in the first hour of classes and it was growing rapidly from one lesson to another, reaching the level above $104 \mathrm{CFU} \mathrm{m}^{-3}$.

3. Sports activity in the gym significantly changed the patterns of bacterial size distribution in the air, shifting the peak from the size range of 3.3-4.7 $\mu \mathrm{m}$ to smaller bacteria particles - in the range from 1.1 to $2.1 \mu \mathrm{m}$.

4. The dominant species of bacteria were Gram-positive cocci of the genera Micrococcus and Staphylococcus.

5. It seems that exposure to bacterial aerosol in the tested rooms does not pose a direct risk of acute health effects; however, prolonged inhalation of airborne bacteria may cause some adverse health effects.

6. The way to improve the microbiological quality of air in the tested facilities is to ensure adequate ventilation. It is necessary to install an air supply, mechanical ventilation.

\section{Acknowledgment}

This work was partially supported by the Faculty of Power and Environmental Engineering, Silesian University of Technology as a part of statutory research.

The author would like to thank Dr. Agnieszka Wlazło from the Institute of Occupational Medicine and Environmental Health in Sosnowiec, Poland, for her help in the measurements of the concentration of airborne bacteria in the school sport hall.

\section{Disclosure}

The authors have no conflicts of interest to disclose.

\section{References}

1. (1993) Biological particles in indoor environment. (In:) Indoor Air Quality and Its Impact on Man, Report No.12, Luxembourg. Commission of the European Communities.

2. Burge H (1995) Aerobiology of the indoor environment. Occup Med 10(1): 27-40.

3. Nevalainen A (1989) Bacterial Aerosol in Indoor Air. University of Kuopio, Finland.

4. Li Ch, Kuo YM (1993) Microbiological indoor air quality in subtropical areas. Environ Int 19(3): 233-239.

5. DeKoster JA, Thorne PS (1995) Bioaerosol concentrations in noncompliant, complaint and intervention homes in the Midwest. Am Ind Hyg Assoc J 56(6): 576-580. 
6. Pastuszka JS, Paw U KT, Lis DO, Wlazło A, Ulfig K (2000) Bacterial and fungal aerosol in indoor environment in Upper Silesia, Poland. Atmos Environ 34(22): 3833-3842

7. Sadigh A, Fataei E, Arzanloo M, Imani AA (2020) Determination of bacterial bioaerosol concentration in indoor air of Ardabil Universities in 2020. J Health and Hyg 11(2): 248-256.

8. Jie Y, Houjin H, Feng J, Jie X (2011) The role of airborne microbes in school and its impact on asthma, allergy, and respiratory symptoms among school children. Rev Med Microbiol 22: 84-89.

9. Karwowska E (2003) Microbiological air contamination in some educational settings. Pol J Environ Studies 12(2): 181-185.

10. Kim NY, Kim YR, Kim MK, Cho DW, Kim J (2007) Isolation and characterization of airborne bacteria and fungi in indoor environment of elementary schools. Korean J Microbiol 43(3): 193-200.

11. Stryjkowska Sekulska M, Piotraszewska Pająk A, Szyszka A, Nowicki M, Filipiak M (2007) Microbial quality of indoor air in university room. Pol J Environ Studies 16(4): 623-632.

12. Onet A, Ilies DC, Buhas S, Rahota D, Ilies A, et al. (2018) Microbial air contamination in indoor environment of university sports hall. J Environ Prot and Health 19: 694-703.

13. Kic P, Ruzek L, Popelarova E (2018) Concentration of air-borne microorganisms in sport facilities. Agronomy Res 16(4): 1720-1727.

14. Małecka Adamowicz M, Kubera Ł, Jankowiak E, Dembowska E (2019) Microbial diversity of bioaerosol inside sport facilities and antibiotic resistance of isolated Staphylococcus spp. Aerobiologia 35: 731-742.

15. Salonen H, Salthammer T, Morawska L (2020) Human exposure to air contaminants in sport environments. Indoor Air 30(6): 1109-1129.

16. Turbeville SD, Cowan LD, Greenfield RA (2006) Infectious disease outbreaks in competitive sports: a review of the literature. Am J Sports Med 34(11): 1860-1865.

17. LaBelle MW, Knapik DM, Arbogast JW, Zhou S, Bowersock L, et al. (2019) Infection risk reduction program on pathogens in high school and collegiate athletic training rooms. Sports and Health 12(1): 51-57.

18. Nevalainen A, Pastuszka J, Liebhaber F, Willeke K (1992) Performance of bioaerosol samplers: collection characteristics and sampler design consideration. Atmos. Environ 26(4): 531-540.

19. Zimbro MJ, Powder DA, Miller SM, Wilson G, Johnson JA (2009) Difco and BBL manual. Manual of microbiological culture media. Becton Dickinson and Company.
20. D`Arcy N, Canales M, Spratt DA, Lai K (2012) Healthy schools: standardization of culturing methods for seeking airborne pathogens in bioaerosols emitted from human sources. Aerobiologia 28: 413-422.

21. Signorile G, Crocitto D, Tato D, Caggiano G (2003) A study of sanitary conditions of gymnasium for recreational sport activities in Bari. Note II: Microclimate and indoor air microbial pollution. Igiene Moderna 119: 23-30.

22. Pegas PN, Alves CA, Evtyugina MG, Nunes T, Cerqueira M, et al. (2011) Indoor air quality in elementary schools of Lisbon in spring. Environ Geochem Health 33(5): 455- 468.

23. Seltzer JM (1995) Biologic contaminants. Occup Med 10(1): 1-23.

24. (2007) Infection prevention and control of epidemic-and pandemicprone acute respiratory diseases in health care. WHO Interim Guides.

25. Menteşe S, Arisoy M, Rad AY, Güllü G (2009) Bacteria and fungi levels in various indoor and outdoor environments in Ankara, Turkey. Clean Soil Air Water 37(6): 487-493.

26. Daisey JM, Angell WJ, Apte MG (2003) Indoor air quality, ventilation and health symptoms in schools: an analysis of existing information. Indoor Air 13(1): 53-64.

27. Goodman RA, Thacker SB, Solomon SL, Osterholm MT, Hughes JM (1994) Infectious diseases in competitive sports. J Am Med Assoc 271(11): 862867.

28. King OS (2009) Infectious disease and boxing. Clinics Sports Med 28(4): 545-560.

29. Likness LP (2011) Common dermatologic infections in athletes and return-to-play guidelines. J Amer Osteopathic Assoc 111(6): 373-379.

30. Brągoszewska E, Mainka A, Pastuszka JS (2016) Bacterial aerosols in an urban nursery school in Gliwice, Poland: a case study. Aerobiologia 32: 469-480

31. US EPA (2011) Exposure Factors Handbook: 2011 Edition. U.S Environmental Protection Agency.

32. Bragoszewska E (2014) Bacterial aerosol occurring in the atmospheric air in Gliwice and its share of the total human exposure to the bacteria absorbed by inhalation. Silesian University of Technology. 